\title{
IMMOBILIZATION OF PSEUDOMONAS SP KLM9 IN SODIUM ALGINATE: A PROMISING TECHNIQUE FOR L-GLUTAMINASE PRODUCTION
}

\author{
Mahesh Divatar, Sandhya G, Sarfraaz Ahemad and Lingappa K \\ Department of post graduate studies and research in Microbiology, \\ Gulbarga University Gulbarga-585106, Karnataka, India. \\ *Address of corresponding author: \\ Dr. K Lingappa, \\ Professor, \\ Department of Microbiology, \\ Gulbarga University Gulbarga-585106, \\ Karnataka, India. \\ Tel: +91 8472 263297; Fax: +91 8472263206 \\ Email: Lingappak2@gmail.com
}

\begin{abstract}
Microbes and process development are gaining considerable importance owing to their exploitation and suitability for the production of the enzymes of therapeutic and industrial significance. In the present study attempts were made to immobilize the Pseudomonas Sp. KLM9 in different supporting matrix to analyze the possible enhancement in the production of L-Glutaminase. The consequences of the study reveal that, sodium alginate at $3.5 \%$ concentration was found to be the better supporting matrix than the others. Further, initial $\mathrm{pH} 7$ of the incubation media, incubation temperature of $37^{\circ} \mathrm{C}$ were supported good yield of L-Glutaminase by immobilized Pseudomonas Sp KLM9. The fermentation period was reduced to $36 \mathrm{hr}$ with immobilized cells. There is moderate increase in the production L-Glutaminase by the immobilized cells than the free cells of Pseudomonas Sp KLM9. Biomass obtained from the $18 \mathrm{hr}$ old culture of Pseudomonas Sp KLM9 was found better to immobilize for the production of L-Glutaminase.
\end{abstract}

Keywords: Pseudomonas sp. KLM9; L-glutaminase production; sodium alginate

\section{INTRODUCTION}

L-Glutaminase [E. C. 3.5.1.2] belongs to the class of hydrolyases and catalysis the hydrolysis of L-Glutamine to L-Glutamic acid liberating ammonia. In the present scenario this enzyme lot of significance owing to its diverse application in several fields such as pharmaceutical and food industry. Studies have revealed that, L-Glutaminase has inhibitory effect on tumor growth (1). L-glutamine is one of the vital amino acid, the tumor cells are the major consumer of L-glutamine, but they are not capable to synthesize this amino acid therefore they compete with host cells for circulating L-glutamine. The L-Glutaminase is used as antineoplastic therapeutic agent as it acts on L-Glutamine and causes the depletion of this amino acid for the tumor cells (2). The L-Glutaminase was found with anti-retroviral effect as it lowers the L-Glutamine level in serum and cause reduction in reverse transcriptase activity of Human 
Immunodeficiency Virus (HIV) (3). L-Glutaminase has biotechnological application as it is used as biosensor for the detection and monitoring of Glutamine concentration in cell culture. Lglutamic acid is one of the key in gradient in soya sauce. This amino acid is formed by two mechanisms; firstly hydrolytic release from raw materials due to protease and peptidase activity secondly, deamidation of Glutamine by Glutaminase (4). The enzyme L-Glutaminase was reported for its use in food industry for the production of soya sauce as it converts L-Glutamine to glutamic acid and provides toothsome taste to the sauce by increasing desirable acidity. Therefore L-Glutaminase has a considerable application in food industry too.

Whole cell immobilization technique is often used improve the bioprocess to get enhanced yield of aimed product. Several matrices were reported as supporting material for immobilizing different microbes including bacteria actinomycetes, fungi and yeast for the production of various biomolecules like antibiotics, enzymes and solvents like alcohols and organic acids (5). Immobilization of whole cell for fermentation purpose has got significant advantage. The immobilized microbial cell can be used repeatedly in many cycles. Immobilized Pseudomonas Sp BTMS-51 was able to produce average yield of L-glutaminase over 20 cycles under repeated batch fermentation (6). Pseudomonas sp was immobilized in different supporting matrix and evaluated for the production of alkaline protease (7). Kuo-Ying-Amada Wu, et al, . studied the immobilization of Pseudomonas in polyvinyl alcohol(PVA) and sodium alginate and its application in phenol degradation (8) and reported that, PVA-alginate beads containing Pseudomonas were strong and durable for phenol degradation in fluidized bed reactor. PVA was proven to be the best supporting matrix in immobilization activated sludge (9). Immobilized Pseudomonas aerugenosa and Bacillus subtilis agar were reported for bioremediation of textile effluents (10). Promod et al,. reported the increased production of citric acid cells than free cells of Aspergillus niger (11).

All of these attempts on immobilization of microbes were mainly targeted to increase the activity of microbe with respect to their application and probability of their reuse. Plenty of studies were conducted and reported on whole cell immobilization and their application to develop possible bioprocess for the production of various biomolecules. In this study Pseudomonas sp KLM9 was immobilized in different supporting matrix and evaluated for LGlutaminase production under submerged fermentation. This study is an attempt to develop bioprocess for the production of L-Glutaminase by Pseudomonas sp KLM9.

\section{MATERIALS AND METHODS}

\section{Chemicals and reagents}

Chemicals and reagents which were used in the present study were procured from Himedia Pvt Ltd. India.

\section{Microorganism}

The Pseudomonas sp KLM9 is a soil bacterium, isolated from Gulbarga University soil sample and maintaining on nutrient agar at the Department of Microbiology, Gulbarga University, Gulbarga, Karnataka, India.

\section{Fermentation media and its Preparation}

In this study safflower oil cake (SFOC) extract was used as fermentation media. Media was prepared as per the method prescribed by Amena et al..(12). Five grams of powdered SFOC was mixed in $100 \mathrm{ml}$ of distilled water heated up to boil for releasing of nutritional content. This 
mixture was cooled to room temperature, filtered with Whatman filter paper No-1 and thus obtained filtrate's volume was made up to $100 \mathrm{ml}$ with additional distilled water. This filtrate was supplemented with $1 \mathrm{gm}$ of galactose, glucose and fructose, $0.3 \mathrm{gm}$ of ammonium chloride $0.5 \mathrm{gm}$ yeast extract (Mahesh et al,.) (13), sterilized and used as fermentation media.

\section{Preparation of Biomass}

The bacterium Pseudomonas Sp KLM9 was inoculated in 100 nutrient broth and incubated at $37^{\circ} \mathrm{C}$ for 24 hours. Thus obtained culture was aseptically withdrawn in sterile centrifuge tubes, centrifuged at $6000 \mathrm{rpm}$ for 15 minutes cell pellet was collected and washed trice in phosphate saline buffer (PBS) of $\mathrm{pH}$ 7. Thus obtained biomass was mixed in $10 \mathrm{ml}$ of sterilized distilled water and used for immobilization.

\section{Immobilization of Pseudomonas Sp KLM9 in different matrices}

\section{Immobilization in Sodium Alginate}

$3 \mathrm{gm}$ of sodium alginate was dissolved in $90 \mathrm{ml}$ of distilled water heated for some time for the complete dissolution and this mixture was sterilized by autoclaving. The sterilized slurry was brought to room temperature. Cell suspension of Pseudomonas Sp KLM9 was poured into the above mentioned slurry and agitated thoroughly with pre-sterilized glass rod for the uniform distribution of cells. This mixture was taken in sterile syringe and extruded into chilled calcium chloride solution $(0.2 \mathrm{M})$ from the height of $20 \mathrm{~cm}$. Thus formed beads were kept in same solution at $4^{\circ} \mathrm{C}$ for one hour for curing. After curing the beads were washed thrice in sterile distilled water, stored at $4^{\circ} \mathrm{C}$ and used for further studies.

\section{Immobilization in Polyvinyl Alcohol (PVA)}

Immobilization of Pseudomonas Sp KLM9 was done as per the method described by Kuo-Ying-Amada Wu et al,. 13 grams of PVA was dissolved in $90 \mathrm{ml}$ of distilled water heated to boil for complete dissolution. This solution was sterilized and brought to room temperature. Pseudomonas sp KLM9 cell suspension was poured into the cooled PVA and agitated thoroughly with pre-sterilized glass rod for the uniform distribution of cells. This mixture was taken in sterile syringe and extruded into cold saturated solution of boric acid from the height of $20 \mathrm{~cm}$ and allowed them for $24 \mathrm{hr}$ for hardening. These beads were washed thrice in sterile distilled water used for the production of L-Glutaminase.

\section{Immobilization in Gelatin}

The cell suspension was mixed in $1: 1$ ratio (V/V) with $20 \%$ sterile gelatin at $45^{\circ} \mathrm{C}$ and mixed properly. Thus obtained gel was poured onto the sterile petridish. This gel was overlayered with 5\% glutaraldehyde for hardening. The resulting gel was cut into small cubes (3$4 \mathrm{~mm}^{3}$ ) aseptically with razor blade. These cubes were washed in sterile distilled water and used for the analysis of L-Glutaminase production.

\section{Immobilization in K-Caraginan}

Cell suspension of Pseudomonas Sp KLM9 was mixed with $20 \mathrm{ml}$ of $4 \% \mathrm{~K}$-caragenan solution. This mixture was dropped into the $0.3 \mathrm{M}$ potassium chloride solution with sterile 
syringe from the tallness of $20 \mathrm{~cm}$. Thus formed beads were washed with sterile distilled water and used for fermentation process.

\section{Fermentation}

\section{Production of L-Glutaminase by immobilized and free cells of Pseudomonas sp KLM9}

Fermentation was carried out in $250 \mathrm{ml}$ conical flasks each containing $100 \mathrm{ml}$ of fermentation media. One $\mathrm{ml}$ of $24 \mathrm{hr}$ old culture Pseudomonas sp KLM9 was inoculated with a conical flask and other conical flasks were inoculated with immobilized cells of Pseudomonas sp KLM9 in different support matrix and kept for incubation at $37^{\circ} \mathrm{C}$. At every $12 \mathrm{hr} \mathrm{L-Glutaminase}$ assay was analyzed.

\section{Optimization of L-Glutaminase Production}

Fermentation was performed with Pseudomonas sp KLM9 immobilized in calcium alginate to analyze the optimum conditions for the production of L-Glutaminase. Fermentation was carried with fermentation media of initial $\mathrm{pH}$ ranging from 6-8 with variation of 0.5 , incubating temperature ranging from $25-45^{\circ} \mathrm{C}$ with variation of $5^{\circ} \mathrm{C}$ and one flask at $37^{\circ} \mathrm{C}$, this particular temperature was maintained because it was optimized with free cell in previous studies. The enzyme titer was assayed at every $12 \mathrm{hrs}$ of time interval.

\section{Assessment of suitable matrix concentration and biomass old}

To determine the suitable concentration of support matrix, the biomass of Pseudomonas spKLM9 was immobilized in different concentration of sodium alginate at 3.0, 3.5, 4.0 and 4.5\% and used for L-Glutaminase production. Further, biomass obtained at different incubation period such as 12, 18, 24 and $30 \mathrm{hrs}$ were immobilized in $3.5 \%$ sodium alginate and performed fermentation to determine the proper old of biomass for better production of L-Glutaminase after immobilization.

\section{Analysis of L-Glutaminase Activity.}

To determine the enzyme activity, $5 \mathrm{ml}$ of the fermenting broth was withdrawn aseptically from the flasks, was filtered using Whatman filter paper No.1 and then centrifuged (............) at $10,000 \mathrm{~g}$ for $10 \mathrm{~min}$ (5). The supernatant thus obtained was used as crude extract for Lglutaminase assay. Assay of enzyme was carried out as per Imada et al. (...). The enzyme activity was expressed in IU. One IU of L-glutaminase is the amount of enzyme which liberates $1 \mu \mathrm{mole}$ of ammonia per $\mathrm{ml}$ per $\min (\mu \mathrm{mole} / \mathrm{ml} / \mathrm{min})$.

\section{Repeated Batch Fermentation}

Repeated batch fermentation performed to examine the reusability of immobilized cells of Pseudomonas sp KLM9 for L-glutaminase production. In repeated batch fermentation, the fermentation medium was aseptically withdrawn from the flasks and fresh medium was added at every 36 hours and further it was kept for fermentation. The same process was continued to run subsequent batches at every 36 hours. The enzyme titers were determined.

\section{Results and Discussion}

Table 1 depicts the L-Glutaminase production pattern by free and immobilized cells of Pseudomonas KLM9 in different matrices. The analysis of enzyme activity was carried out at every $12 \mathrm{hr}$ of intervals. Among the used matrices sodium alginate supported better enzyme yield 
with 136 IU than the other tested matrices. There are several report suggest that sodium alginate is the suitable matrices for immobilizing microbes for the production of biomolecules including enzymes. Study conducted by Adinarayana et al., reported that sodium alginate is the efficient support matrix to immobilize Bacillus subtilis for the alkaline protease production. (14).The sodium alginate is the best matrix than the other support matrix to immobilize Pseudomonas for the production of protease (7). Productivity of the enzyme was moderately increased by the immobilized cells of Pseudomonas Sp. KLM9 from 126 IU to 136 IU. But even though there might not be considerable increase in enzyme productivity but there is significant reduction in fermentation time to $36 \mathrm{hr}$ from $48 \mathrm{hr}$ which was observed with free cells.

Table.1. Production of L-glutaminase by free cells and immobilized cells of Pseudomonas Sp KLM9

\begin{tabular}{|l|c|c|c|c|c|}
\hline \multirow{2}{*}{ Support Matrix } & \multicolumn{5}{|c|}{ L-Glutaminase Activity (IU) } \\
\cline { 2 - 6 } & $12 \mathrm{hr}$ & $24 \mathrm{hr}$ & $36 \mathrm{hr}$ & $48 \mathrm{hr}$ & $60 \mathrm{hr}$ \\
\hline Free Cells & 09 & 27 & 90 & 126 & 60 \\
\hline Sodium alginate & 20 & 89 & 136 & 48 & 34 \\
\hline Gelatin & 19 & 65 & 118 & 42 & 32 \\
\hline Polyvinyl Alcohol & 02 & 20 & 23 & 18 & 09 \\
\hline K-Caragenan & 10 & 30 & 82 & 48 & 26 \\
\hline
\end{tabular}

Table 2 shows the effect of the different variables on the productivity of L-glutaminase by Pseudomonas Sp KLM9. Immobilized beads with $3.5 \%$ of sodium alginate and $18 \mathrm{hr}$ old biomass of Pseudomonas sp.KLM9 were found to be best for enzyme production. In the study conducted by Sankaralingam et al., reports that, there will be variations in support matrix concentration with respect to matrix used for immobilizing Pseudomonas. Further the investigation revealed that, $5 \%$ sodium alginate is the best concentration to immobilize Pseudomonas for protease production (7). However, Pseudomonas sp.KLM9 entrapped in sodium alginate were significantly increased the enzyme yield with the activity from 125 IU to 162 IU. Figure 1 shows the L-Glutaminase productivity by free and immobilized cells of Pseudomonas sp KLM9. Lingappa et al., reported the considerable reduction in fermentation time along with considerable increase in the L-Asperginase production with immobilized cells of Streptomyces gulbergensis (15).

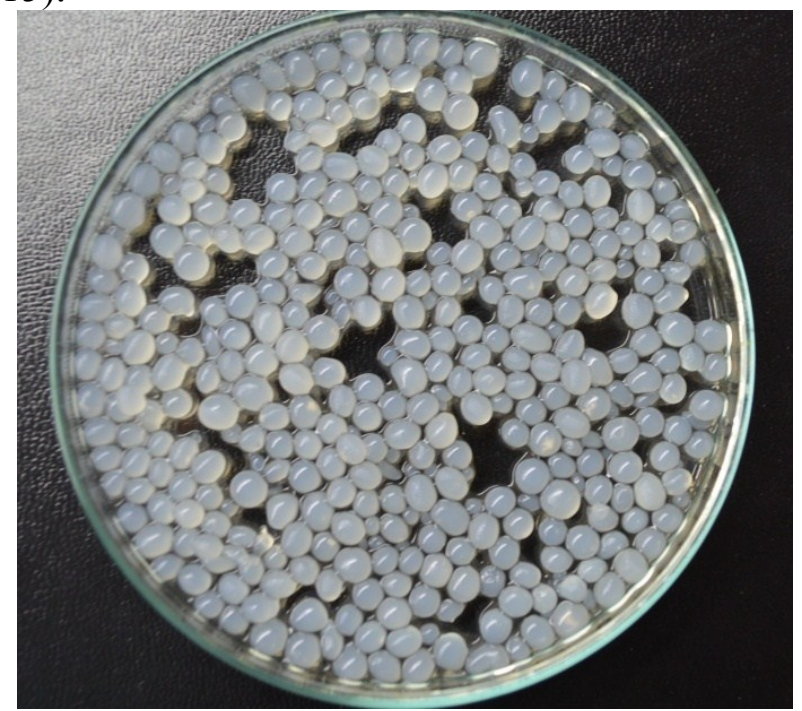

Plate.1. Sodium Alginate beads Containing Pseudomonas sp KLM9 


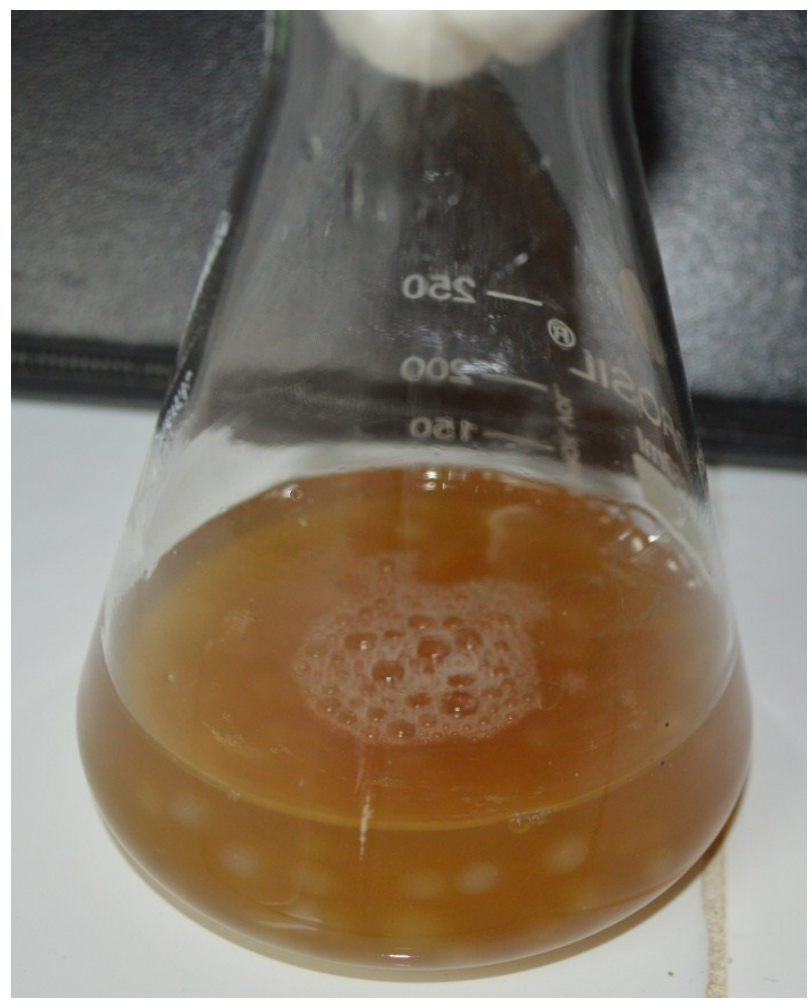

Plate. 2. L-Glutaminase Production by Immobilized Pseudomonas Sp KLM9 under Submerged Fermentation

Table. 2. Effect of Different Variables on L-glutaminase Production by immobilized Pseudomonas Sp KLM9

\begin{tabular}{|c|c|c|c|c|c|}
\hline Variables and Their Range & \multicolumn{5}{|c|}{ L-Glutaminase Activity (IU) } \\
\cline { 2 - 6 } & \multicolumn{5}{|c|}{ Fermentation time } \\
\hline $\mathrm{pH}$ & 12 & 24 & 36 & 48 & 60 \\
\hline 6.0 & 16 & 63 & 103 & 28 & 20 \\
\hline 6.5 & 29 & 76 & 114 & 33 & 24 \\
\hline 7.0 & 21 & 91 & 129 & 46 & 26 \\
\hline 7.5 & 20 & 88 & 118 & 44 & 25 \\
\hline 8.0 & 12 & 41 & 76 & 27 & 19 \\
\hline Temperature $\left({ }^{\circ} \mathrm{C}\right)$ & & & & & \\
\hline 25 & 06 & 22 & 36 & 18 & 14 \\
\hline 30 & 11 & 37 & 44 & 22 & 18 \\
\hline 35 & 21 & 86 & 131 & 52 & 34 \\
\hline 40 & 20 & 79 & 130 & 54 & 32 \\
\hline 45 & 17 & 58 & 94 & 38 & 21 \\
\hline
\end{tabular}




\begin{tabular}{|c|c|c|c|c|c|}
\hline 37 & 29 & 80 & 139 & 54 & 36 \\
\hline $\begin{array}{c}\text { Sodium Alginate } \\
\text { concentration (\%) }\end{array}$ & & & & & \\
\hline 3.0 & 28 & 82 & 138 & 55 & 38 \\
\hline 3.5 & 30 & 80 & 145 & 55 & 37 \\
\hline 4.0 & 14 & 56 & 110 & 48 & 30 \\
\hline 4.5 & 06 & 40 & 58 & 42 & 28 \\
\hline Biomass Old (hr) & 10 & 39 & 53 & 39 & 31 \\
\hline 12 & 35 & 89 & 162 & 59 & 39 \\
\hline 18 & 29 & 82 & 144 & 48 & 32 \\
\hline 24 & 20 & 72 & 122 & 46 & 32 \\
\hline 30 & & & & & \\
\hline
\end{tabular}

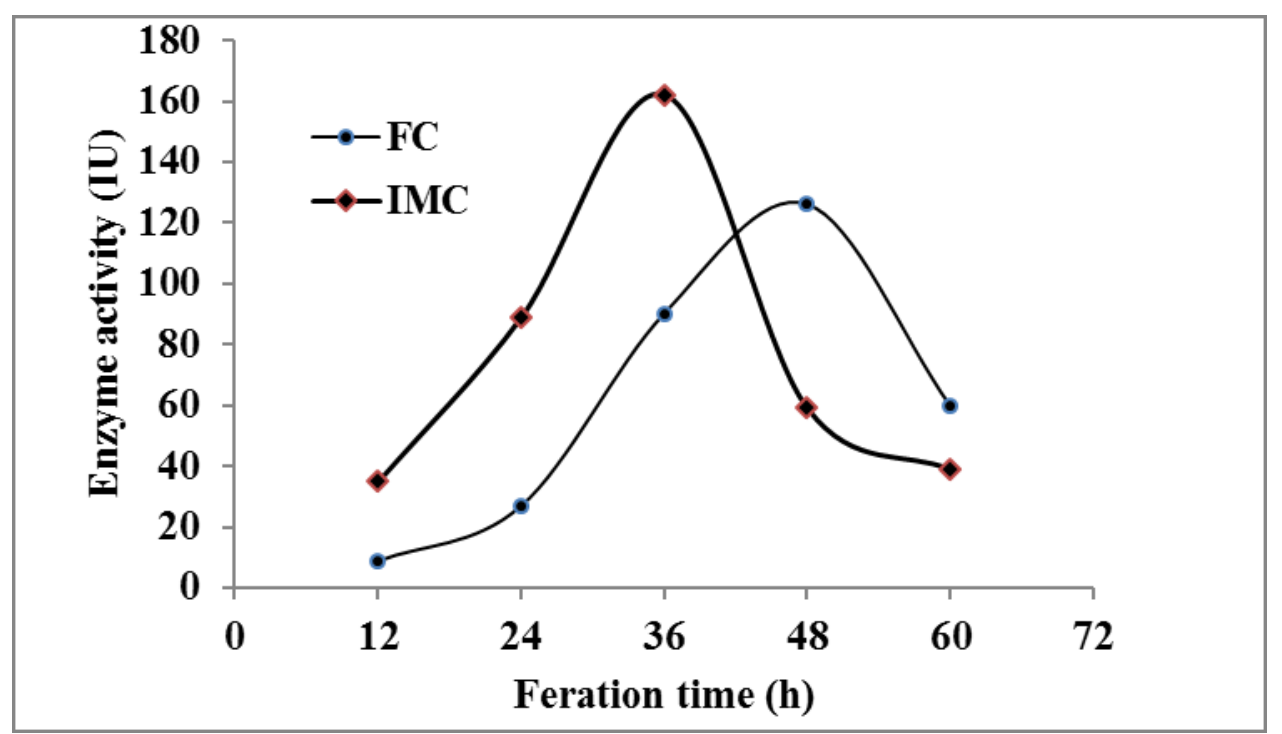

Figure.1. L-Glutaminase Productivity by free and immobilized cells of Pseudomonas Sp. KLM9 in Sodium Alginate

Figure 2 depicts the productivity of L-Glutaminase by immobilized Pseudomonas sp KLM9 under repeated batch fermentation. In repeated batch fermentation the enzyme titer was remain constant for initial four cycles with 163 IU thereafter the enzyme productivity was slightly decreased and this was continued to another three cycles further there was declivity found. A total of seven cycles were found suitable for reusability of immobilized cells of Pseudomonas sp. KLM9 for L-Glutaminase production. The average enzyme yield from seven cycles under repeated batch fermentation was $160 \mathrm{IU}$. 


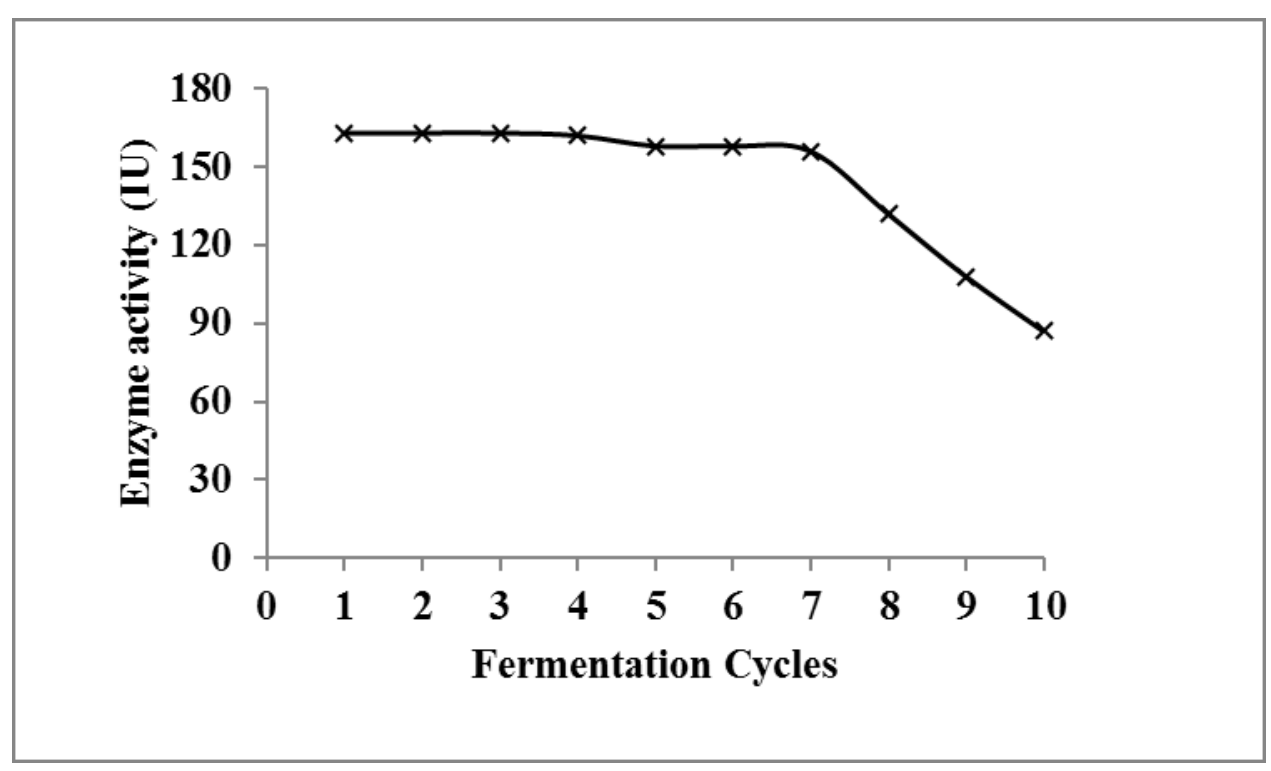

Figure.2. L-Glutaminase Productivity by immobilized cells of Pseudomonas Sp. KLM9 in Repeated Batch Fermentation

\section{CONCLUSION}

The consequences this study revealed that, sodium alginate is the promising support matrix to immobilize Pseudomonas Sp KLM9 for the production of L-Glutaminase submerged fermentation. Further $3.5 \%$ of sodium alginate concentration and $18 \mathrm{~h}$ old biomass was found better for whole cell immobilization. Under all optimized condition the enzyme production is 162 IU. In repeated batch fermentation, the immobilized Pseudomonas Sp. KLM9 produce good enzyme yield up to seven cycles.

\section{ACKNOWLEDGEMENT}

The authors are great full to Department of Biotechnology, Ministry odf science \& Technology, New Delhi, India. for financial assistance.

\section{References}

[1] Farid A. El-asmar and David M. Greenberg. Studies on the Mechanism of Inhibition of Tumor Growth by the Enzyme Glutaminase. Cancer Research 26, 16-12. (1966).

[2] Wiley W Soub. Glutamine and cancer. Annals of Surgery. (1993).

[3] J Roberts and W G McGregor. Inhibition of mouse retroviral disease by bioactive glutaminase-asparaginase. Journal of General Virology. 72 ( Pt 2):299-305. (1991).

[4] Alexandra Weingand, Christane Gerber-Decombaz, Michael Affolter. Functional Characterization of a salt and Thermotallerant glutaminase from Lactobacillus rhamnosus. Enzyne and Microbial Technology. 32, 862-867. (2003).

[5] S V Ramakrishna and S Prakasham. Microbial Fermentation with Immobilized cells. Current science. 77,1-10. (1999).

[6] S Rajeev Kumar and m chandrashekaran. Continuos Production of L-Glutaminase by an immobilized marime Pseudomonas sp BTMS-51 in Packed Bed reactor. Process Biochemistry. 38, 1431-1436. (2002). 
[7] S Sankarlingam., T Shankar., K SendeskannanR Ramasubburayan and S Prakash. Europ. J. Appl. Sci. 4 (4), 146-156. (2012).

[8] Kuo-Ying-Amada Wu and Keith D Wisecaver. Cell immobilization Using PVA crossed linked with Boric acid. Biotechnology and Bioengineering. 39(4). (1991).

[9] Zhang Li Sheng., WuWei-Zhong and Wang Jian Long. Immobilization of Activated Sludge Using improved polyvinyl Alcohol (PVA) Gel. Journal of environmental Science. 19, 1293-1297. (2007).

[10] Ajao A T, Adebayo G b and Yakubu S E. Bioremidiation of Textile Industrial Effluents Using mixed Culture of Pseudomonas arugenosa and Bacillus subtilis. J. Micribiol. Res. , 1 (3), 50-56. (2011).

[11] Pramod T and Lingappa K. Immobilization of Aspergillus niger in Henn White for the Production of citric acid using Carob pod extract. J. Micribiol. Res., 2 (2), 265-269. (2012).

[12] Amena S, Vishalaxi N, Prabhakar M and Lingappa K. Production Purification and Characterization of L-Asperginase Streptomyces gulbergensis. Brazilian journal of Microbiology., 41.173-178. (2010).

[13] Mahesh Divatar, Prabhakar M and Lingappa K. Evaluation of Bioprocess, Raw materials and Conditions for the Production of L-Glutaminase by Pseudomonas Sp.KLM9. Asian Journal of Biochemical and Pharmaceutical Research., 1(4) (2013).

[14] Kunamneni Adinarayana, Bezawada Jyothi and Poluri Ellaiah. Production of Alkaline Protease With Immobilized Cells of Bacillus subtilis PE-11 in Various Matrices by Entrapment Technique. AAPS PharmSciTech 6 (3) (2005).

[15] Lingappa Kattimani, Syeda amena, Vishalakshi N and Prabhakar M. immobilization of Streptomyces gubergensis in polyurethane foam: A promising technique for L-Asperginase Production. Iranian Journal of biotechnology. 7 (4) (2009) 